\title{
Physiological effects of gasoline on the freshwater fish Prochilodus lineatus (Characiformes: Prochilodontidae)
}

\author{
Juliana D. Simonato ${ }^{1}$, Marisa N. Fernandes² and Cláudia B. R. Martinez ${ }^{1}$
}

\begin{abstract}
The purpose of this work was to evaluate the effects of the water-soluble fraction of gasoline (WSFG) on the Neotropical freshwater fish Prochilodus lineatus. The WSFG was prepared by mixing gasoline in water (1:4) and animals were exposed for 6, 24 and $96 \mathrm{~h}$ to $5 \%$ diluted WSFG or only to water. After exposure, blood was collected from the caudal vein and the gills were removed. The following parameters were analyzed: hematological (hemoglobin, hematocrit, number of red blood cells), osmo-ionic (plasma $\mathrm{Na}^{+}, \mathrm{Cl}^{-}$and $\mathrm{K}^{+}$and plasma osmolarity), metabolic (total plasma proteins and glucose), endocrine (cortisol), density and distribution of chloride cells [CC] in the gills (immunohistochemistry), and branchial $\mathrm{Na}^{+} / \mathrm{K}^{+}$-ATPase (NKA) activity. Hemolysis was found to occur after $96 \mathrm{~h}$ exposure to WSFG, as indicated by the decrease in the hematological parameters analyzed, followed by an increase in plasma $\mathrm{K}^{+}$. Secondary stress response was revealed by the occurrence of hyperglycemia in the three periods of exposure, despite the absence of significant increases in the plasma cortisol. The exposure to WSFG also caused an increase in the quantity of CC and in plasma $\mathrm{Na}^{+}$, after $24 \mathrm{~h}$, as well as in the enzymatic activity of NKA and plasma osmolarity, after $24 \mathrm{~h}$ and $96 \mathrm{~h}$. These results indicate that fish exposed to the WSFG showed physiological adjusts to maintain their osmotic balance. However, the increase in the quantity of CC in the lamellae may interfere in the gas exchange impairing respiration.
\end{abstract}

O objetivo deste trabalho foi avaliar os efeitos da fração solúvel da gasolina (FSG) em Prochilodus lineatus. A FSG foi preparada misturando-se a gasolina à água (1:4) e os animais foram expostos por 6, 24 e 96h à FSG diluída 5\% ou apenas à água. Após a exposição, o sangue foi coletado pela veia caudal e as brânquias foram retiradas. Os seguintes parâmetros foram analisados: hematológicos (hemoglobina, hematócrito, quantidade de células vermelhas), osmo-iônicos (concentrações plasmáticas de $\mathrm{Na}^{+}, \mathrm{Cl}^{-}, \mathrm{K}^{+}$e osmolaridade), metabólicos (concentrações plasmáticas de proteínas totais e glicose), endócrino (cortisol plasmático), densidade e distribuição de células-cloreto [CC] nas brânquias (imunohistoquímica) e a atividade da enzima $\mathrm{Na}^{+} / \mathrm{K}^{+}$-ATPase (NKA) branquial. Hemólise foi observada após $96 \mathrm{~h}$ de exposição à $\mathrm{FSG}$, indicada pela diminuição dos parâmetros hematológicos analisados, seguido pelo aumento do $\mathrm{K}^{+}$ plasmático. Houve resposta secundária de estresse visualizada pela ocorrência da hiperglicemia nos três tempos de exposição, apesar da ausência de diferenças significativas na concentração plasmática do cortisol. A exposição à FSG também provocou aumento na quantidade das CC e na concentração de $\mathrm{Na}^{+}$, após $24 \mathrm{~h}$, e na atividade enzimática da NKA e osmolaridade, após $24 \mathrm{~h}$ e $96 \mathrm{~h}$. Esses resultados indicam que peixes expostos à FSG apresentaram ajustes fisiológicos para manter o equilíbrio osmótico. Entretanto, o aumento na quantidade de CC nas lamelas pode ter interferido nas trocas gasosas prejudicando a respiração.

Key words: Chloride cells, Hematology, Hydrocarbons, $\mathrm{Na}^{+} \mathrm{K}^{+}$-ATPase, Osmoregulation, Stress response.

\section{Introduction}

The gills are the first organ to come in contact with contaminants in water and, as such, are an entryway for pollutants given their large contact surface and high permeability (Dang et al., 2000). Studies have confirmed that the main pathway of absorption of hydrocarbons dissolved in water is through the gills, because they are a highly dynamic organ which is exposed directly to contaminated waters (Ahmad et al., 2003). This organ possesses a variety of functions in freshwater fish, and is also the main organ responsible for gas exchange, metabolic waste excretion, ion regulation, and acid-base equilibrium (Mayer-Gostan et al., 1987; Heath, 1995; Goss et al., 1998; Hwang \& Lee, 2007).

\footnotetext{
${ }^{1}$ Universidade Estadual de Londrina, Departamento de Ciências Fisiológicas, Caixa Postal 10011, 86057-970 Londrina, PR, Brazil. jsimonato@uel.br(JDS),cbueno@uel.br(CBRM)

${ }^{2}$ Universidade Federal de São Carlos, Departamento de Ciências Fisiológicas, Caixa Postal 676, 13565-905 São Carlos, SP, Brazil. dmnf@ufscar.br
} 
Many stressors can affect the branchial structure and, directly or indirectly, gas exchange and hydromineral balance, which are the main reasons for the vulnerability of these animals in polluted waters (Hwang \& Lee, 2007). Because it represents the barrier between the external and internal environment, this tissue is highly susceptible to environmental changes (Wendelaar Bonga \& Lock, 2008). Thus the gills are considered target organs for the immediate effects of chemicals diluted in water (Oliveira et al., 2008).

Osmoregulation is essential for the survival of freshwater fish, since the environment in which they live has a high ion gradient, favoring the loss of ions. Freshwater fish capture ions actively through the gills, including $\mathrm{Ca}^{2+}, \mathrm{Na}^{+}$, and $\mathrm{Cl}^{-}$(Mayer-Gostan et al., 1987; Bindon et al., 1994; Hirose et al., 2003;). This ionic regulation by the gills occurs principally as a function of the presence of the chloride cells (CC) (Bindon et al., 1994; Hirose et al., 2003), normally located in the branchial filaments close to the base of the lamellae (Perry, 1997). The chloride cells play an essential role in maintaining the ionic balance of the internal environment, absorbing $\mathrm{Na}^{+}$ and $\mathrm{Cl}^{-}$(Bindon et al., 1994). These cells are rich in mitochondria and have several ATPases such as $\mathrm{Na}^{+} / \mathrm{K}^{+}$ATPase (NKA) and $\mathrm{Ca}^{2+}$-ATPase. They also have $\mathrm{Ca}^{2+}$ and $\mathrm{Na}^{+}$channels, as well as exchangers such as $\mathrm{Cl}^{-} / \mathrm{HCO}_{3}^{-}$, which reflects their importance in the transport of ions across the gills (Perry, 1997; Claiborne et al., 2002). Disturbances in the water balance and in ionic homeostasis are characteristic aspects of stress in fish and occur due to the intimate relationship between the body fluids in the gills and the aquatic environment (Wendelaar Bonga, 1997). Therefore, plasma osmolarity and individual concentrations of different ions (Baldisserotto et al., 2012), complemented by the results of quantity of CC and NKA activity, are examples of important parameters that serve as indicators of the sublethal effects of pollutants in fish (Camargo et al., 2009).

The presence of chemical products in the aquatic environment can also trigger several physiological responses, collectively called stress response. This response represents the perception of an altered state that triggers neuroendocrine responses which are part of a chain of generalized reactions promoted by a stressor. In fish, the neuroendocrine responses to stress, called primary responses, include the rapid release of hormones into the circulation, such as catecholamines and cortisol. This is followed by the so-called secondary stress response, which comprises several biochemical and physiological adjustments associated and mediated by these hormones and leads to hematological, osmo-ionic and metabolic changes. These alterations are indicators of secondary stress response and have been widely used as biomarkers in fish (Teles et al., 2005; Simonato et al., 2008; Oliveira et al., 2011).

Hematological parameters in fish may also vary as a direct effect of the pollutant in the blood cells and these changes are important because they reflect the occurrence of environmental alterations that make blood parameters good indicators of the health of aquatic animals exposed to contaminants (Davison et al., 1993). Changes in hematological parameters have already been found in fish exposed to different types of petroleum and derivatives (Davison et al., 1993; Alkindi et al., 1996; Duarte et al., 2010) but it is evident that the hematological responses may vary among species and different pollutants, and additional information such as ion concentrations and osmolarity are necessary to define a relationship between the pollutant and the variations observed.

Among the different types of water pollutants, petroleum derivatives are of special concern for aquatic ecotoxicology both because the frequency of contamination events as well as due to the high toxic potential of their compounds (Pacheco \& Santos, 2001; Tiburtius et al., 2004). Gasoline is the most common automotive fuel and is widely used throughout the world. The contamination of water by this petroleum derivative is mainly attributed to small but continuous leaks in storage tanks that reach water bodies, thus it is important to understand the toxic potential of gasoline for aquatic organisms (Simonato et al., 2011).

The species Prochilodus lineatus (Valenciennes, 1837) (Characiformes, Prochilodontidae) is a species native to Brazil's southern and southeastern regions, and is considered one of the most important species in the Paraná River basin. In addition to its ecological value, it is also economically important for the region (Cazenave et al., 2009). Several studies have demonstrated that this species is highly sensitive to different contaminants (Camargo et al., 2009; Modesto \& Martinez, 2010; Garcia \& Martinez, 2012; Santos \& Martinez, 2012; Pereira et al., 2013), including petroleum derivatives (Simonato et al., 2006, 2008, 2011). All these features make the $P$. lineatus a suitable biological model for environmental monitoring.

Thus, the objective of this study was to analyze the metabolic, hematological, osmo-ionic and enzymatic parameters in order to evaluate the effects and/or responses of $P$. lineatus exposed to water-soluble fraction of gasoline (WSFG).

\section{Material and Methods}

Experimental animals. Juveniles of Prochilodus lineatus were supplied by the Fish Hatchery Station of the State University of Londrina, with a body mass of $11.23 \pm 4.67 \mathrm{~g}$ (mean $\pm \mathrm{SD}, \mathrm{N}=96$ ). The animals were acclimated for seven days in a 300-liter tank containing dechlorinated water, with constant aeration, $\mathrm{pH}$, dissolved oxygen, and photoperiod of $12 \mathrm{~h}$ light: $12 \mathrm{~h}$ dark. The fish were fed commercial fish food at 48-hour intervals. Fish were not fed during and on the day preceding the experiments.

Water-soluble fraction of gasoline (WSFG). Gasoline was purchased from a specific gas station. The methodology 
employed to simulate fuel leakage followed that proposed by Nicodem et al. (1998). The gasoline was mixed with water in a proportion of 1 part gasoline to 4 parts water (forming a film); the mixture was allowed to rest for 24 hours. During this period, the mixture was exposed to direct sunlight for 6 hours (from 10 am to $4 \mathrm{pm}$ ) on a cloudless day. The aqueous phase was separated and used in the exposure assays, while the organic phase (insoluble) was discarded. Samples of water from the experimental groups were examined qualitatively for the presence of mono- and polyaromatic hydrocarbons as described in the Simonato et al. (2011)

Toxicity tests. The fish were submitted to acute static toxicity tests for 6, 24 and 96h. A group of fish exposed to WSFG (EXP), and a control group exposed only to water (CTR), were used for each experimental time. The tests were carried out in 100-liter glass aquaria containing 8 fish each. The fish were exposed to WSFG diluted to $5 \%$ (4 L of WSFG:76 L of water) according to Simonato et al. (2011). A control group was sampled simultaneously to the group exposed to WSFG after each period of exposure $(6,24$ and 96h). Replications were carried out for each aquarium (EXP and CTR). The physical and chemical characteristics of the media water were monitored daily for temperature, dissolved oxygen, $\mathrm{pH}$, and conductivity.

Immediately after removing the fish from the aquaria, they were anesthetized with benzocaine $\left(0.1 \mathrm{~g} \mathrm{~L}^{-1}\right)$ and blood samples were taken from the caudal vein, using heparinized plastic syringes, after that, animals were killed by medullar section. These procedures were performed according to the protocol approved by the Animal Experiments Committee of Londrina State University. The gills were removed and processed for immunohistochemical against $\mathrm{Na}^{+} / \mathrm{K}^{+}$-ATPase and enzyme assay. Immediately after sampling, part of the blood was centrifuged $(10 \mathrm{~min}, 3000 \times \mathrm{g})$ and samples of plasma were frozen $\left(-20^{\circ} \mathrm{C}\right)$ for osmolarity, ion concentrations, cortisol, glucose and protein analyses.

Hematological analyses Aliquots of blood were used for the determination of hematocrit (Hct), by microcentrifugation in capillary tubes. The hemoglobin $(\mathrm{Hb})$ content was determined by the cyanmethemoglobin method in a spectrophotometer at $540 \mathrm{~nm}$, using a commercial kit (Analisa, Brazil). Total erythrocytes count (RBC) was determined from an aliquot of total blood fixed in formolcitrate buffer $(0.13 \mathrm{M}$ sodium citrate diluted in $0.4 \%$ of formol), using an improved Neubauer hemocytometer under light microscope (400x magnification).

Plasma concentrations of cortisol, glucose proteins and osmo-ionic. Plasma cortisol was determined by an immunoenzymatic assay (commercial kit from Diagnostic Systems, Laboratories, USA) on microplates at $450 \mathrm{~nm}$ (Simonato et al., 2008). The glucose concentration was determined by the glucose oxidase method in a spectrophotometer at $505 \mathrm{~nm}$ (commercial kit from Labtest,
Brazil). The plasma concentration of total protein was determined according to the method of Lowry et al. (1951), using bovine serum albumin (BSA) as standard in a spectrophotometer at $700 \mathrm{~nm}$. Plasma aliquots were used to determine the concentration of sodium $\left(\mathrm{Na}^{+}\right)$and potassium $\left(\mathrm{K}^{+}\right)$ions in a flame photometer (Analyzer, Brazil). The concentration of chloride $\left(\mathrm{Cl}^{-}\right)$was determined in a spectrophotometer at $470 \mathrm{~nm}$, using the mercury thiocyanate method (commercial kit from Analisa, Brazil). Osmolarity was determined by freezing point, using a micro-osmometer (Osmomat 030, Gonotec, Germany).

Identification of chloride cells in the gills. The gills were washed with saline solution and samples from the gill were fixed in Bouin's fluid (6h), dehydrated in ethanol crescent series and embedded in paraffin. Sagittal sections $(8 \mathrm{~mm}$ in thickness) were made and processed according to the avidinbiotin-peroxidase complex (ABC) technique to visualize chloride cells, through the identification of $\mathrm{Na}^{+} / \mathrm{K}^{+}$-ATPase, according to Carmargo et al. (2009). Slides were incubated with a mouse monoclonal antibody to $\mathrm{Na}^{+} / \mathrm{K}^{+}$-ATPase (IgG $\alpha 5$ ) and goat-anti-mouse IgG was used as the second antiserum. Subsequently, 3-3-diaminobenzidine (DAB 0.05M) in Trisbuffered saline ( $\mathrm{pH} 7.4)$, containing $\mathrm{H}_{2} \mathrm{O}_{2}(0.03 \%)$ was applied. Finally, sections were dehydrated and mounted. The chloride cells were quantified in relation to the filament length ( $\mathrm{mm})$ according to their localization: in the gill filament (CCF) or in the gill lamellae (CCL), using a photomicroscope (DM 2500, Leica, Germany) and an image analyser (Leica Qwin, Germany). For each section from the same fish, five filaments were randomly selected and measured for $\mathrm{CC}$ quantification. The results were expressed as the number of $\mathrm{CC}$ per $\mathrm{mm}$ of filament (mean $\pm \mathrm{SD}$ ).

$\mathrm{Na}^{+} / \mathrm{K}^{+}$-ATPase enzyme activity in the gills. After washing, the branchial arches were placed in plastic tubes containing SEI buffer (Sucrose 300 mM; EDTA $0.1 \mathrm{mM}$; Imidazole $30 \mathrm{mM}$; $\beta$-mercaptoethanol $0.035 \% ; \mathrm{pH} 7.4$ ) and frozen $\left(-20^{\circ} \mathrm{C}\right)$ until the moment of the enzymatic assay. The branchial filaments were homogenized with SEI buffer (10x the volume) and centrifuged $\left(7800 \mathrm{~g}, 15 \mathrm{~min}, 4^{\circ} \mathrm{C}\right)$. The supernatant was used to determine $\mathrm{Na}^{+} / \mathrm{K}^{+}$-ATPase enzyme activity according to the method described by Quabius et al. (1997) and adapted to a microplate reader by Nolan (2000). The assay consists of determining the release of phosphate by samples incubated in buffer $(\mathrm{NaCl} 100 \mathrm{mM}$; $\mathrm{MgCl}_{2} 8 \mathrm{mM}$; imidazole $30 \mathrm{mM}$; EDTA $0.1 \mathrm{mM}$; ATP $3 \mathrm{mM}$; $\mathrm{pH} 7.6)$ containing $\mathrm{KCl}(13 \mathrm{mM})$ or ouabain $(2.5 \mathrm{mM})$. A $0.65 \mathrm{mM}$ phosphate solution (Sigma) was used as standard and the samples were analyzed in triplicate at $620 \mathrm{~nm}$ in a microplate reader (ELX 800, BioTek, USA). The NKA activity was expressed as $\mu \mathrm{mol} \mathrm{Pi} \mathrm{mg}_{\text {protein }}^{-1} \mathrm{~h}^{-1}$.

Statistical analysis. The results obtained for the control and experimental groups at each exposure time were compared to each other using Student's parametric $t$-test or 
Mann-Whitney's non-parametric test, depending on the distribution of the data. The decision to use parametric or non-parametric tests was based on analyses of normality and homogeneity of variance. Values were considered significant when $\mathrm{P}<0.05$.

\section{Results}

Water parameters. The physicochemical characteristics (mean \pm SEM) remained stable throughout the experimental times for both control (temperature $21.8 \pm 0.2^{\circ} \mathrm{C}, \mathrm{pH} 7.2 \pm$ 0.1 , DO $7.1 \pm 0.4 \mathrm{mg} \mathrm{O}_{2} \mathrm{~L}^{-1}$ and conductivity $116.6 \pm 0.8 \mu \mathrm{S}$ $\mathrm{cm}^{-1}$ ) and WSFG groups (temperature $21.1 \pm 0.2^{\circ} \mathrm{C} ; \mathrm{pH} 7.3 \pm$ 0.1 , DO $7.4 \pm 0.3 \mathrm{mg} \mathrm{O}_{2} \mathrm{~L}^{-1}$ and conductivity $88.6 \pm 1,5 \mu \mathrm{S}$ $\left.\mathrm{cm}^{-1}\right)$. The WSFG was analyzed before dilution $(100 \%)$ and showed high concentrations of BTEX (benzene, toluene,
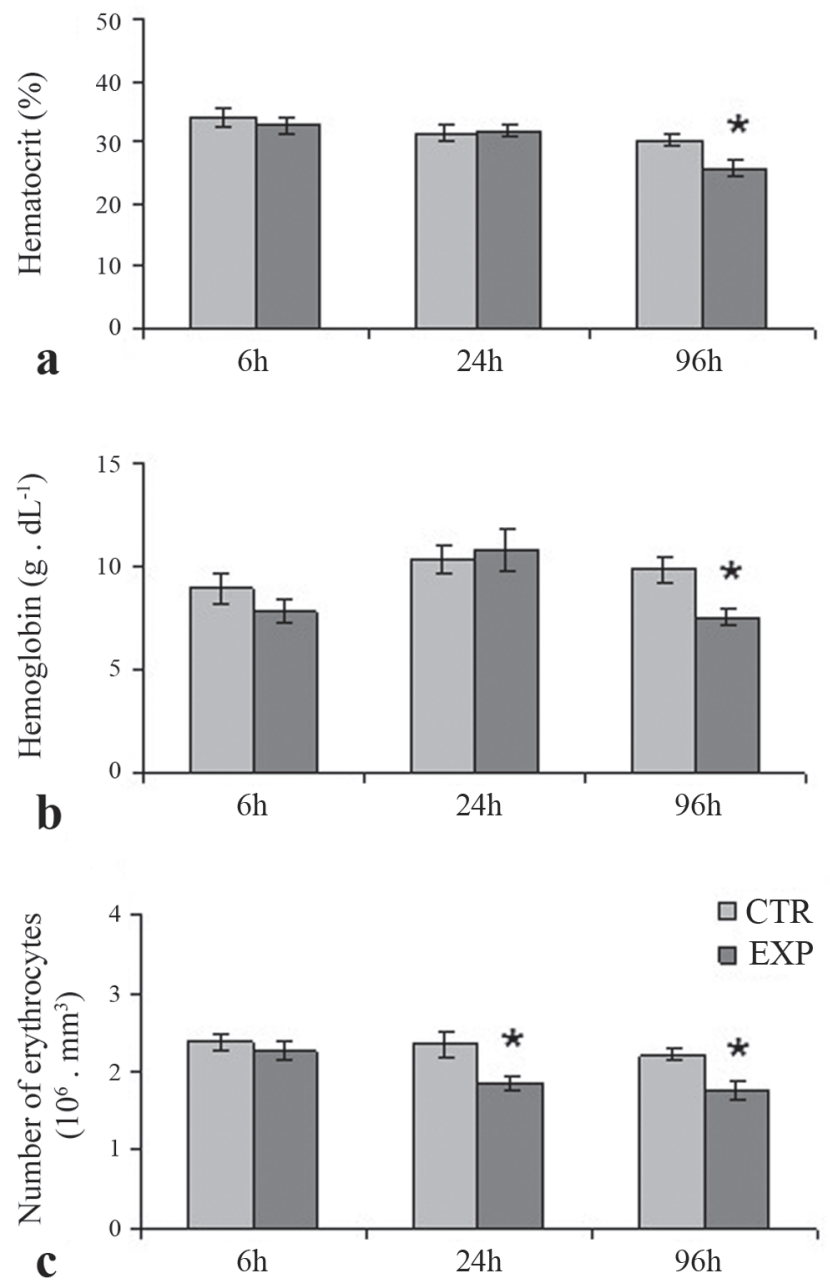

Fig. 1. Hematocrit (a), hemoglobin (b) and number of erythrocytes (c) in Prochilodus lineatus exposed to WSFG (EXP) or only to water (CTR) for 6, 24 and 96h. Data are means $\pm \operatorname{SEM}(\mathrm{n}=10-13)$, asterisks indicate different from respective control $(\mathrm{P}<0.05)$. ethylbenzene, and xylene), mainly of ethylbenzene (10500 $\left.\mu \mathrm{g} \mathrm{L}^{-1}\right)$, xylene $\left(7550 \mu \mathrm{g} \mathrm{L}^{-1}\right)$ and benzene $\left(5700 \mu \mathrm{g} \mathrm{L}^{-1}\right)$. The concentration of 12 PAHs (polyaromatic hydrocarbons) were determined in the $100 \%$ WSFG and among them naphthalene was the most significant $\left(2138.25 \mu \mathrm{g} \mathrm{L}^{-1}\right)$, followed by anthracene $\left(53.25 \mu \mathrm{g} \mathrm{L}^{-1}\right)$ and phenanthrene $\left(12.20 \mu \mathrm{g} \mathrm{L}^{-1}\right)$ as already reported by Simonato et al. (2011).

Hematological, metabolic and osmo-ionic parameters. The fish exposed to WSFG for $96 \mathrm{~h}$ presented significantly lower hematocrit (Fig. 1a) and hemoglobin (Fig. 1b) values than respective CTR groups. The RBC counts (Fig. 1c) of fish exposed to WSFG showed a significant reduction after 24 and 96h in comparison to CTR groups.

The plasma glucose of animals exposed to WSFG presented a significant increase in relation to respective
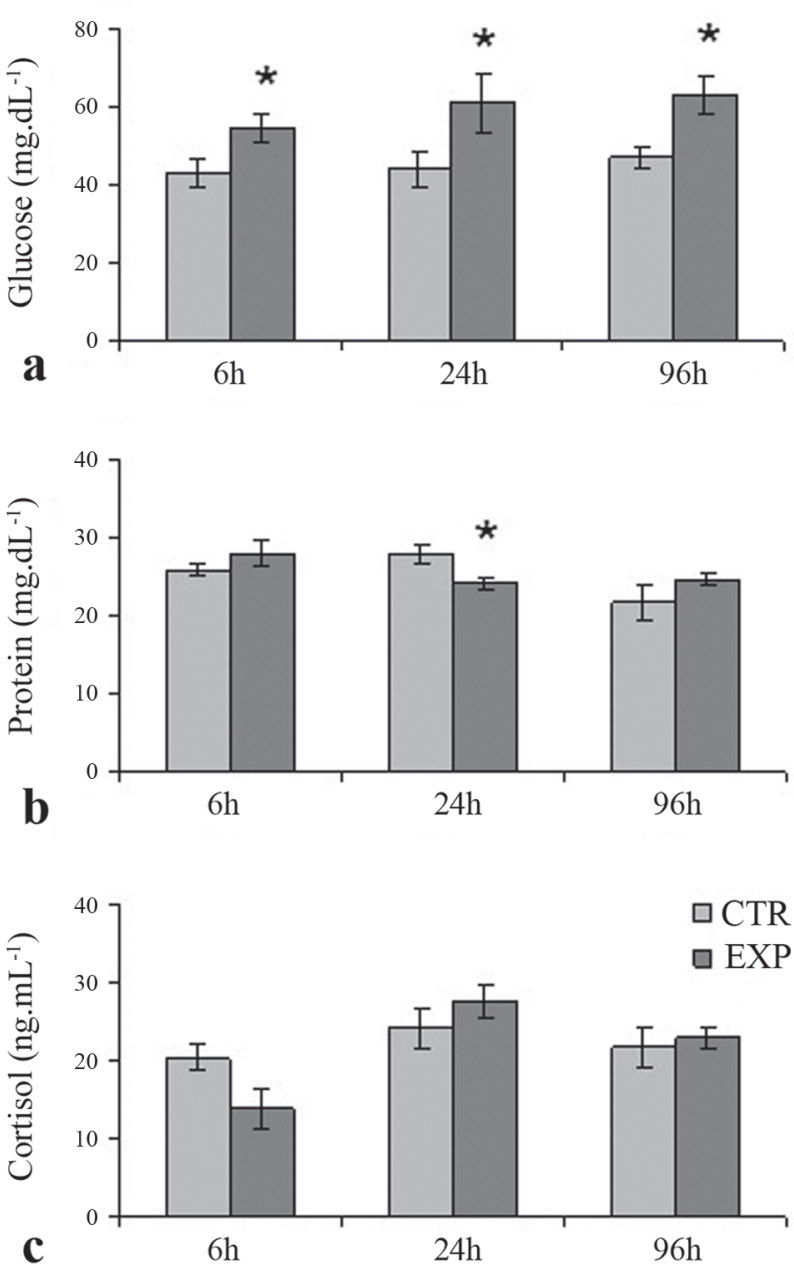

Fig. 2. Plasma concentrations of glucose (a), proteins (b) and cortisol (c) in Prochilodus lineatus exposed to WSFG (EXP) or only to water (CTR) for 6, 24 and 96h. Data are means \pm SEM $(n=10-13)$, asterisks indicate different from respective control $(\mathrm{P}<0.05)$. 
controls in the three experimental times (Fig. 2a). The values of plasma protein declined in fish after 24h exposure to WSFG when compared to the respective controls (Fig. 2b). Plasma cortisol did not vary significantly between control and WSFG exposed groups at any experimental period (Fig. 2c). Plasma osmolarity (Fig. 3a) was significantly higher in fish exposed to WSFG for $24 \mathrm{~h}$ and $96 \mathrm{~h}$ in comparison with respective controls. The plasma $\mathrm{Na}^{+}$concentration (Fig. 3b) increased significantly only after $24 \mathrm{~h}$ of exposure to WSFG when compared with the control group. In the animals exposed to WSFG for $96 \mathrm{~h}$, the plasma $\mathrm{K}^{+}$concentration (Fig. 3c) was significantly higher than in the fish of the CTR group. The plasma $\mathrm{Cl}^{-}$concentration did not vary significantly between control and WSFG exposed groups at any experimental period (Fig. 3d).
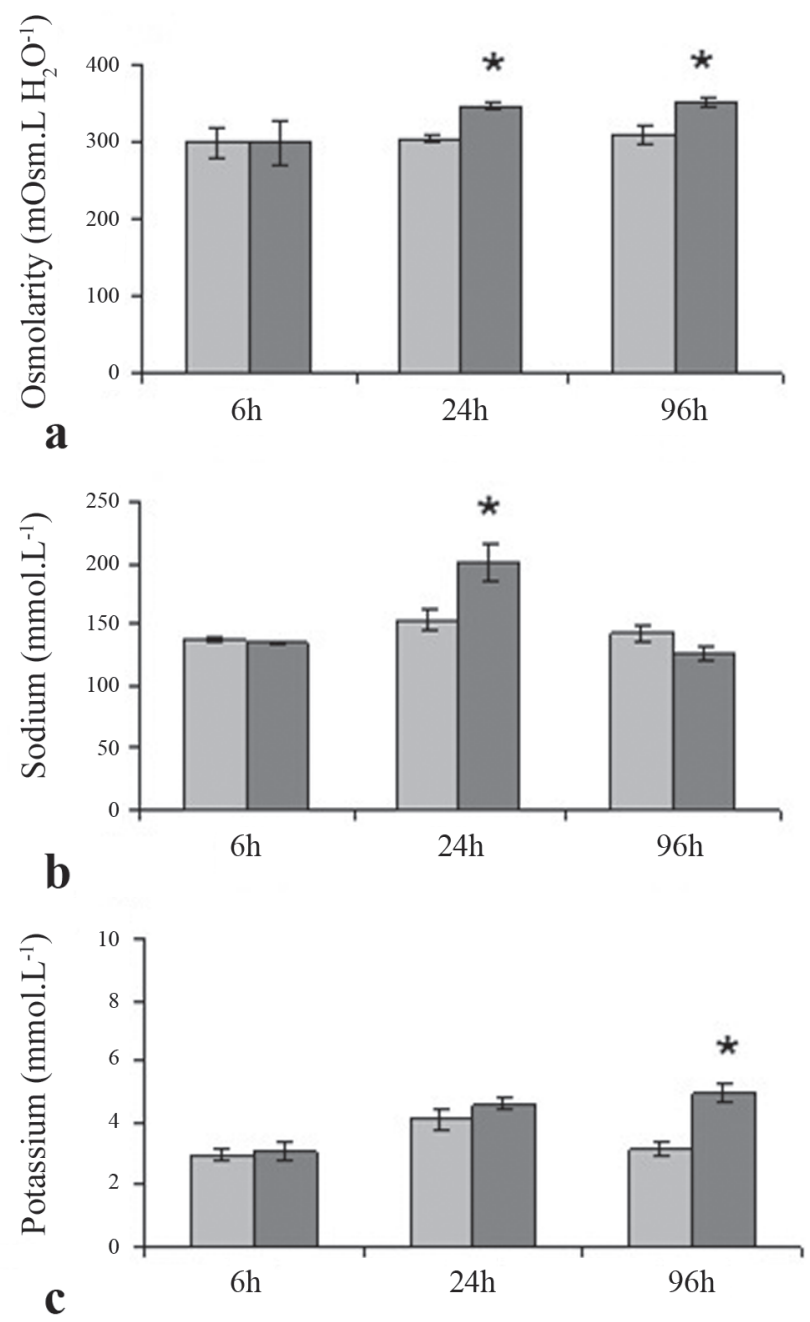

Fig. 3. Plasma osmolarity (a) and concentrations of $\mathrm{Na}^{+}(\mathbf{b})$, $\mathrm{K}^{+}(\mathbf{c})$ and $\mathrm{Cl}^{-}(\mathbf{d})$ of Prochilodus lineatus exposed to WSFG (EXP) or only to water (CTR) for 6, 24 and 96h. Data are means $\pm \operatorname{SEM}(\mathrm{n}=10-13)$, asterisks indicate different from respective control $(\mathrm{P}<0.05)$.

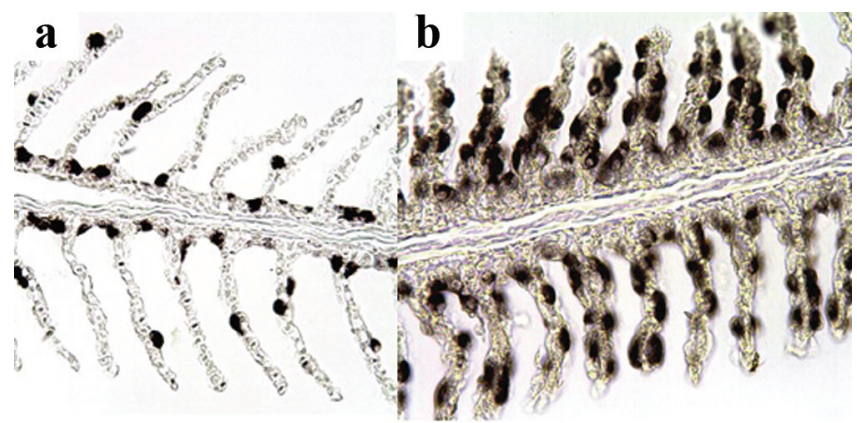

Fig. 4. Immunohistochemistry location of the $\mathrm{Na}+/ \mathrm{K}+-$ ATPase enzyme in the chloride cells (CC) of $P$. lineatus exposed to only to water (a) or WSFG (b) for 24h. Original magnification: $400 \mathrm{X}$.

Distribution and density of chloride cells (CC) in the gills. The Figure 4 shows $\mathrm{CC}$ identified by the immunohistochemical reaction in the gills of the animals after $24 \mathrm{~h}$ of exposure to water (CTR) or to WSFG (EXP). In the animals of the control group (Fig. 4a), CC were located preferentially at the base of the lamella next to the filament. However, in the animals of the experimental group (Fig. 4b), the $\mathrm{CC}$ were more numerous and distributed mainly in the lamellae. Figure 5 illustrates this significant increase in the number of CC in the lamellae (CCL) of fish exposed to WSFG for $24 \mathrm{~h}$, after comparison with the CTR animals. The sum of the $\mathrm{CC}$ found in the filament and lamellae, designated as the total number of CC (TCC), increased significantly in the animals exposed to WSFG for $24 \mathrm{~h}$ relative to the CTR group. No variation was found between CTR and WSFG groups at any other experimental times.

$\mathbf{N A}^{+} / \mathbf{K}^{+}$-ATPase (NKA) activity in the gills. The NKA enzyme activity in the gills of fish exposed to WSFG for $24 \mathrm{~h}$ and $96 \mathrm{~h}$ showed a significant increase in comparison to the respective CTR groups (Fig. 6).

\section{Discussion}

The WSFG promoted important changes in Prochilodus lineatus, including hemolysis, which was indicated by a decrease in the hematological parameters, followed by an increase in plasma $\mathrm{K}^{+}$in $96 \mathrm{~h}$. Similar results have been found for this fish species after exposure to diesel oil (Simonato et $a l ., 2008)$. There was also an indication of secondary stress response due to the occurrence of hyperglycemia at the three exposure times, despite the absence of increases in the plasma cortisol concentration. WSFG also caused an increase in the quantity of CC and in NKA activity in the animals after $24 \mathrm{~h}$ of exposure.

Changes in the hematological parameters of fish reflect the environmental alterations experienced by these organisms. Hence, these parameters are good indicators of 


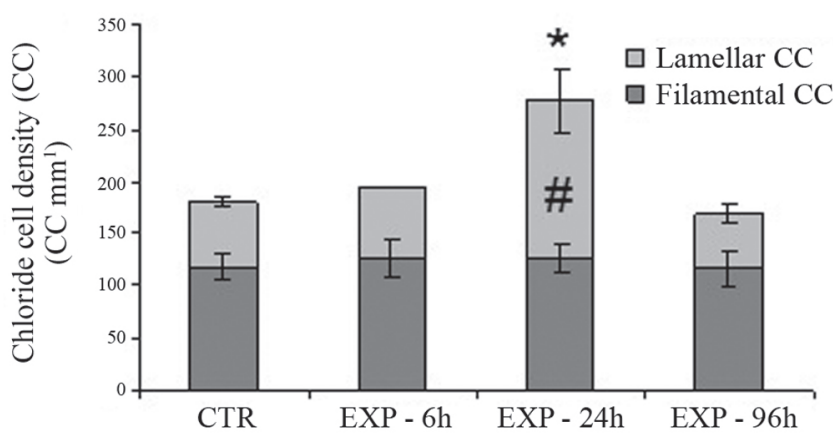

Fig. 5. Density of chloride cells $\left(\mathrm{CCmm}^{-1}\right)$ in the lamellar and lamental regions of the gills of Prochilodus lineatus exposed to WSFG (EXP) for 6, 24 and 96h. The results obtained for control groups at each experimental period were pooled together (CTR). Data are means $\pm \operatorname{SEM}(\mathrm{n}=10-13)$, asterisks indicate number of total CC different from CTR group; number sign indicate number of lamellar CC different from CTR group $(\mathrm{P}<0.05)$.

the health of aquatic animals exposed to contaminants, since they constitute one of the first detectable stress responses caused by environmental changes (Davison et al., 1993). In the present study, the exposure of fish to WSFG for 96h led to decreased hematocrit, hemoglobin content and number of erythrocytes, and to augmented values of plasma $\mathrm{K}^{+}$. Taken as a whole, these findings indicate that the increase in $\mathrm{K}^{+}$must have occurred as a result of hemolysis, since this ion normally appears in larger quantities inside the erythrocytes. Hemolysis may impair the oxygen capture and gas exchange capacity of these animals, as well as interfere in the acid-base equilibrium (Bloom \& Brandt, 2008). Similar findings have been reported for Prochilodus lineatus exposed to the water-soluble fraction of diesel oil (Simonato et al., 2008) and for flounder (Pleuronectes flesus) after exposure to the water-soluble fraction of crude oil (Alkindi et al., 1996). According to Duarte et al. (2010), the hydrocarbons in petroleum seriously impair oxygen transport, since they are known to alter the permeability of erythrocytes with a strong hemolytic effect.

Exposure to gasoline induced hyperglycemia in the three experimental times, and reduced protein concentrations after $24 \mathrm{~h}$, indicating the availability of energy reserves for immediate use. Mobilization of energy reserves is described as a typical secondary stress response and can be mediated by the release of catecholamines or cortisol (Heath, 1995; Iwama et al., 2006). The purpose of the stress response is to maintain or reestablish homeostasis due to physical and/or chemical changes that may compromise the survival of the organism exposed to a stressor (Wendelaar Bonga, 1997). Therefore, it should be emphasized that stress responses are of vital importance for the survival of the organism. Available glucose is important because it provides an energy substrate for tissues such as brain, muscles and gills to

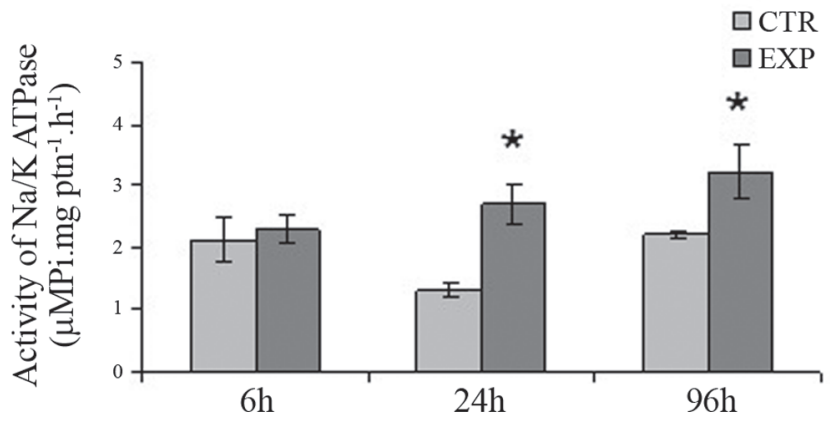

Fig. 6. Activity of $\mathrm{Na}^{+} / \mathrm{K}^{+}$-ATPase in the gills of Prochilodus lineatus exposed to WSFG (EXP) or only to water (CTR) for 6, 24 and 96h. Data are means \pm SEM $(n=10-13)$, asterisks indicate different from respective control $(\mathrm{P}<0.05)$.

enable the animal to respond defensively to the stressor. Increased plasma glucose has already been observed in other studies after exposure to polycyclic aromatic hydrocarbons (PAHs) (Vijayan et al., 1997; Pacheco \& Santos 2001). As mentioned earlier, the mobilization of energy can be mediated by cortisol or catecholamines. Mommsen et al. (1999) state that, in addition to promoting hyperglycemia, cortisol is also responsible for proteolysis in fish, probably related to adjustments in amino acid metabolism which promote gluconeogenesis. On the other hand, catecholamine release is considered a compensatory response to optimize cardiovascular and respiratory function, and may also mobilize energy reserves to supply the metabolism increased by stress-related demands (Fabbri et al., 1998). Several authors assert that the fact that catecholamines are released through the rapid pathway (sympathetic nervous system) and are readily eliminated from circulation, so that hyperglycemia is maintained during exposure of up to $96 \mathrm{~h}$, as was found in the present study, is likely the result of cortisol release (Wendelaar Bonga, 1997; Iwama et al., 2006). However, according to Fabbri et al. (1998), hyperglycemia after $24 \mathrm{~h}$ of exposure may also be an effect of catecholamines. This is confirmed by the findings of Gesto et al. (2006), who observed that naphthalene induced the release of noradrenaline in rainbow trout after 24 and $72 \mathrm{~h}$ of exposure.

There is still much controversy about the relationship between cortisol and catecholamine release and the hyperglycemia observed in situations of stress. According to Vijayan et al. (1997), the hyperglycemia identified in their study could not be correlated to catecholamines, since it is improbable that these hormones persist for up to $48 \mathrm{~h}$. These authors attributed the increased glucose to increased gluconeogenesis in the liver induced by previously released cortisol. Another aspect of hyperglycemia generated after exposure to contaminants is discussed by Vijayan et al. (1997) and Aluru \& Vijayan (2006), who stated that xenobiotics that 
are able to induce P450 augment the hepatic cortisol catabolism, suggesting that the compounds that induce cytochrome P450 enzymes can affect the concentration of cortisol. A study conducted by Tintos et al. (2007) found that fish intoxicated with naphthalene showed augmented plasma glycemia. Other authors state that this activation of energy metabolism may also occur to supply energy for detoxification processes, as indicated by the increased activity of the hepatic biotransformation enzymes glutathione-S-transferase (GST) and 7-ethoxyresorun- $O$-deethylase (EROD). Hence, augmented glucose may also have occurred to make energy available for these processes.

In the present study, the levels of plasma cortisol did not show significant variations. This absence of variation may suggest that cortisol was released in the first few hours after the stress, which precluded recording an increase in the plasma concentration of this hormone. This was also suggested by Iwama et al. (2006), who stated that this hormone returns to its basal level a few hours after its release. However, secondary responses were detected, such as hyperglycemia, possible proteolysis, and changes in the quantity of CC. Hyperglycemia was also reported for eels (Anguilla anguilla) exposed to the water-soluble fraction of gasoline (Pacheco \& Santos, 2001) and for Prochilodus lineatus exposed to the water-soluble fraction of diesel for up to $96 \mathrm{~h}$ (Simonato et al., 2008).

Pollutants can alter the ionic balance since they reach organs that are directly involved in osmoregulation, metabolism or in active transport processes (Baldisserotto et $a l ., 2012)$. The gills are considered a target organ for contaminants, due to their large surface area in contact with the external environment (Mayer-Gostan et al., 1987; Dang et al., 2000). NKA is the enzyme responsible for the active transport of $\mathrm{Na}^{+}$and $\mathrm{K}^{+}$ions, maintaining the balance of the ionic gradient, and is present in high concentrations in the $\mathrm{CC}$ and gills of teleosts. NKA is important not only to support intracellular homeostasis but also to aid other transport systems in the gills (Hwang \& Lee, 2007). In this study, the fish exposed to WSFG presented augmented concentrations of $\mathrm{Na}^{+}$and of plasma osmolarity, accompanied by an increase in the quantity of CC in the lamellae and of NKA activity after $24 \mathrm{~h}$ of exposure to WSFG. These results reflect stimulation of the pathways to $\mathrm{Na}^{+}$uptake, as demonstrated by the activation of NKA, which resulted in an increase in $\mathrm{Na}^{+}$concentration and plasma osmolarity. This increase in NKA activity, in turn, resulted, at least in part, from the differentiation of $\mathrm{CC}$ in the gills, as indicated by the augmented density of CC in the gills of $P$. lineatus. Taken together, these responses indicate that fish exposed to the WSFG showed physiological adjusts to maintain their osmotic balance.

According to Perry (1997), CC are more restricted to the interlamellar region of the filament epithelium at the base of the lamellae. However, in this study, the increase observed in the quantity of CC of animals exposed to WSFG for $24 \mathrm{~h}$ occurred in the lamellae. This proliferation of $\mathrm{CC}$ in the lamellae may be a way for these cells to reach the bloodstream as a mechanism of defense of the organism to increase the capture of ions (Perry, 1997; Dang et al., 2000). The presence of CC in the lamellar epithelium may indicate an adaptation to the reduced concentration of ions in the water, in order to augment the capacity for active ion transport through the gills (Fernandes \& Perna-Martins, 2001). Conversely, in the case of the present study, it may indicate difficulty in ion capture due to the presence of toxic agents in the water. According to Sloman et al. (2001), cortisol increases the ion transport capacity in the gills through the proliferation of CC. Despite the absence of a change in the plasma cortisol of these animals, it is plausible to infer that the latter was released, based on the detection of secondary stress responses. On the other hand, this proliferation of $\mathrm{CC}$ in the lamellae may hinder the gas exchanges needed for respiration (Perry, 1997). This fact was confirmed by the work developed by Bindon et al. (1994), who concluded that the proliferation of CC impaired the transfer of respiratory gases in the gills of the animals under study. This reduction in gas exchanges as an effect of the proliferation of CC is due to thickening of the water-blood diffusion barrier, which consequently restricts the passage of the water flux through the interlamellar area (Bindon et al., 1994).

After 96h of exposure to WSFG, the number of CC did not show significant differences, but the NKA remained elevated. It can be inferred that the excess $\mathrm{CC}$ were eliminated to prevent impairment of respiration and that the NKA remained elevated to compensate for a possible ionic disorder provoked by the contaminants present in the WSFG. According to Bury et al. (1998), cortisol induces CC apoptosis and changes in the branchial epithelium may be part of an integrated stress response. Moreover, according to Wendelaar Bonga (1997), exposure to stressor agents may promote apoptosis of CC, but this apoptosis does not necessarily also reduce NKA activity, because the remaining cells may compensate for the absence of the others. This reestablishment of the quantity of CC may have occurred so that their increase would not provoke deleterious consequences for respiratory homeostasis. The hypothesis that the excess of $\mathrm{CC}$ was eliminated to prevent impairment of the respiration of these animals is supported by Goss et al. (1998), who found a reduction in the quantity of CC in animals exposed to hypercapnia and this decrease occurred to enable restoration of the acid-base equilibrium of the blood. In addition, hypercapnia may promote a release of catecholamines to regulate the blood $\mathrm{pH}$ (Brauner \& Val, 2006). According to Goss et al. (1998), hypercapnia can be corrected by an increase in the capture of $\mathrm{Na}^{+}$, which will result in the elimination of the acid. Thus, the increase in CC may have impaired the exchange of gases, leading to hypercapnia, which then caused the release of catecholamines. The release of these hormones led to hyperglycemia and, to regulate the acid-base equilibrium of the blood, there was a greater capture of $\mathrm{Na}^{+}$and the consequent elimination of $\mathrm{H}^{+}$. This increase in $\mathrm{Na}^{+}$triggered an increase in NKA activity to regulate the ionic balance. 
The results demonstrated that the monoaromatic and polyaromatic hydrocarbons in the WSFG 5\%, even at low concentrations, were able to trigger hemolysis, as indicated by the decrease in the hematological parameters analyzed here, followed by an increase in plasma $\mathrm{K}^{+}$, probably as an effect of cellular pro-oxidant imbalance. The fish exposed to WSFG also showed a secondary stress response, which was indicated by the occurrence of hyperglycemia in all the periods of exposure, despite the absence of significant differences in the plasma concentration of cortisol, reflecting the need for adjustments to enable the animal to respond to this stressor agent. WSFG also promoted modifications in the ionic regulation of the gills, which resulted in increased CC density, NKA activity, plasma $\mathrm{Na}^{+}$concentrations and osmolarity in the animals exposed to WSFG for 24h. Taken together, these results demonstrate the importance of the use of physiological biomarkers in the evaluation of areas impacted by gasoline.

\section{Acknowledgments}

The authors thank the Hatchery Station of the State University of Londrina for supplying the fish for this research. This work is part of the doctoral thesis of J. D. Simonato. CNPq (Conselho Nacional de Desenvolvimento Científico e Tecnológico), FAPESP (Fundação de Amparo à Pesquisa do Estado de São Paulo) and Fundação Araucária provided financial support for this work. M. N. Fernandes and C. B. R. Martinez are research fellows from $\mathrm{CNPq}$ and members of the Brazilian Institute of Aquatic Toxicology (INCT-TA, CNPq: 573949/2008-5).

\section{Literature Cited}

Ahmad, I., M. Pacheco \& M. A. Santos. 2003. Naphthaleneinduced differential tissue damage association with circulating ûsh phagocyte induction. Ecotoxicology and Environmental Safety, 54: 7-15.

Alkindi, A. Y. A., J. A. Brown, C. P. Waring \& J. E. Collins. 1996. Endocrine, osmoregulatory, respiratory and haematological parameters in flounder exposed to the water soluble fraction of crude oil. Journal of Fish Biology, 49: 1291-1305.

Aluru, N. \& M. M. Vijayan. 2006. Aryl hydrocarbon receptor activation impairs cortisol response to stress in rainbow trout by disrupting the rate-limiting steps in steroidogenesis. Endocrinology, 147: 1895-1903.

Baldisserotto, B., L. O. Garcia, A. P. Benaduce, R. N. Duarte, T. L. Nascimento, L. C. Gomes, A. R. C. Gomes, A. L. Val. 2012. Sodium fluxes in tamoatá, Hoplosternum litoralle, exposed to formation water from Urucu Reserve (Amazon, Brazil). Archives of Environmental Contamination and Toxicology, 62: 78-84.

Bindon, S. D., K. M. Gilmour, J. C. Fenwick \& S. F. Perry. 1994. The effects of branchial chloride cell proliferation on respiratory function in the rainbow trout Oncorhynchus mykiss. Journal of Experimental Biology, 197: 47-63.

Bloom, J. C. \& J. T. Brandt. 2008. Toxic responses of the blood. Pp. 455-484. In: Klaassen, C. D. (Ed.) Casarett and Doull's Toxicology: The Basic Science of Poisons. Kansas, McGrawHill Professional.
Brauner, C. J. \& A. L. Val. 2006. Oxygen transfer. Pp. 277-300. In: Val, A. L., V. M. F. Almeida-Val \& D. J. Randall (Eds.). The Physiology of Tropical Fishes. Amsterdam, Academic Press.

Bury, N. R., L. Jie, G. Flik, R. A. C. Lock \& S. E. Wendelaar Bonga. 1998. Cortisol protects against copper induced necrosis and promotes apoptosis in fish gill chloride cells in vitro. Aquatic Toxicology, 40: 193-202.

Camargo, M. M. P., M. N. Fernandes \& C. B. R. Martinez. 2009. How aluminium exposure promotes osmoregulatory disturbances in the neotropical freshwater fish Prochilodus lineatus. Aquatic Toxicology, 94: 40-46.

Cazenave, J., C. Bacchetta, M. J. Parma, P. A. Scarabotti \& D. A Wunderlin. 2009. Multiple biomarkers responses in Prochilodus lineatus allowed assessing changes in the water quality of Salado River basin (Santa Fe Argentina). Environmental Pollution, 157: 3025-3033.

Claiborne, J. B., S. L. Edwards \& A. I. Morrison-Shetlar. 2002. Acid-Base regulation in fishes: cellular and molecular mechanisms. Journal of Experimental Zoology, 293: 302-319.

Dang, Z., R. A. C. Lock, G. Flik \& S. E. Wendelaar Bonga. 2000. $\mathrm{Na}^{+} / \mathrm{K}^{+}$-ATPase immunoreactivity in branchial chloride cells of Oreochromis mossambicus exposed to copper. Journal of Experimental Biology, 203: 379-387.

Davison, W., C. E. Franklin, J. C. Mckenzie \& P. W. Carey. 1993. The effects of chronic exposure to the water soluble fraction of fuel oil on an antarctic fish Pagothenia borchgrevinki. Comparative Biochemistry and Physiology C, 104: 67-70.

Duarte, R. M., R. T. Honda \& A. L. Val. 2010. Acute effects of chemically dispersed crude oil on gill ion regulation, plasma ion levels and haematological parameters in tambaqui (Colossoma macropomum). Aquatic Toxicology, 97: 134-141.

Fabbri, E., A. Capuzzo \& T. W. Moon. 1998. The role of circulating catecholamines in the regulation of fish metabolism: an overview. Comparative Biochemistry and Physiology C, 120: 77-192.

Fernandes, M. N. \& S. A. Perna-Martins. 2001. Epithelial gill cells in the armored catfish Hypostomus cf. plecostomus (Loricariidae). Revista Brasileira de Biologia, 61: 69-78.

Garcia, C. Z. \& C. B. R. Martinez. 2012. Biochemical and genetic alterations in a freshwater neotropical fish after acute exposure to Microcystis aeruginosa. Neotropical Ichthyology, 10: 613-622.

Gesto, M., A. Tintos, J. L. Soengas \& J. M. Míguez. 2006. Effects of acute and prolonged naphthalene exposure on brain monoaminergic neurotransmitters in rainbow trout (Oncorhynchus mykiss). Comparative Biochemistry and Physiology C, 144: 173-183.

Goss, G. G., S. F. Perry, J. N. Fryer \& P. Laurent. 1998. Gill morphology and acid-base regulation in freshwater fishes. Comparative Biochemistry and Physiology A, 119: 107-115.

Heath, A. G. 1995. Water Pollution and Fish Physiology. $2^{\text {nd }}$ ed. Boca Raton, Florida.

Hirose, S., T. Kaneko, N. Naito \& Y. Takei. 2003. Molecular biology of major components of chloride cells. Comparative Biochemistry and Physiology B, 136: 593-620.

Hwang, P. P. \& T. H. Lee. 2007. New insights into fish ion regulation and mitochondrion-rich cells. Comparative Biochemistry and Physiology A, 148: 479-497.

Iwama, G. K., L. O. B. Afonso \& M. M. Vijayan. 2006. Stress in fish. Pp. 319-342. In: Evans, D. H. \& J. B. Claiborne (Eds.). The Physiology of Fishes. New York, CRC Press.

Lowry, O. H., N. J. Rosenbrough, A. L. Farr \& R. J. Randall. 1951. Protein measurements with the Folin phenol reagent. Journal of Biology Chemistry, 193: 265-275. 
Mayer-Gostan, N., S. E. Wendelaar Bonga \& P. H. M. Balm. 1987. Mechanisms of hormone actions on gill transport. Vertebrate Endocrinology: Fundamentals and Biomedical Implications, 2: $1-238$.

Modesto, K. A. \& C. B. R. Martinez. 2010. Roundup causes oxidative stress in liver and inhibits acetylcholinesterase in muscle and brain of the fish Prochilodus lineatus. Chemosphere, 78: 294-299.

Mommsen, T. P., M. M. Vijayan \& T. W. Moon. 1999. Cortisol in teleosts: dynamics mechanisms of action and metabolic regulation. Reviews in Fish Biology and Fisheries, 9: 211-268.

Nicodem, D. E., C. L. B. Guedes \& R. J. Correa. 1998. Photochemistry of petroleum: I systematic study of a Brazilian intermediate crude oil. Marine Chemistry, 63: 93-104.

Nolan, D. T. 2000. Skin response of fish to stressors. Ph.D. Dissertation, Catholic University of Nijmegen, Holand, 182p.

Oliveira, M., M. Pacheco \& M. A. Santos. 2008. Organ specific antioxidant responses in golden grey mullet (Liza aurata) following a short-term exposure to phenanthrene. Science of the Total Environment, 396: 70-78.

Oliveira, M., M. Pacheco \& M. A. Santos. 2011. Fish thyroidal and stress responses in contamination monitoring - An integrated biomarker approach. Ecotoxicology and Environmental Safety, 74: 1265-1270.

Pacheco, M. \& M. A. Santos. 2001. Biotransformation, endocrine, and genetic responses of Anguilla anguilla L. to petroleum distillate products and environmentally contaminated waters. Ecotoxicology and Environmental Safety, 49: 64-75.

Pereira, L., M. N. Fernandes \& C. B. R. Martinez. 2013. Hematological and biochemical alterations in the fish Prochilodus lineatus caused by the herbicide clomazone. Environmental Toxicology and Pharmacology, 36: 1-8.

Perry, S. F. 1997. The chloride cell: structure and function in the gills of freshwater fishes. Annual Review of Physiology, 59: 325-47.

Quabius, E. S., P. H. M. Balm \& S. E. Wendelaar Bonga. 1997. Interrenal stress responsiveness of tilapia (Oreochromis mossambicus) is impaired by dietary exposure to PCB 126. General and Comparative Endocrinology, 108: 472-482.

Santos, T. G \& C. B. R. Martinez. 2012. Atrazine promotes biochemical changes and DNA damage in a Neotropical fish species. Chemosphere, 89: 1118-1125.
Simonato, J. D., A. C. Albinati \& C. B. R. Martinez. 2006. Effects of the water soluble fraction of diesel fuel oil on some functional parameters of the neotropical freshwater fish Prochilodus lineatus Valenciennes. Bulletin of Environmental Contamination and Toxicology, 76: 505-511.

Simonato, J. D., C. L. B. Guedes \& C. B. R. Martinez. 2008. Biochemical, physiological and histological changes in the neotropical fish Prochilodus lineatus exposed to diesel oil. Ecotoxicology and Environmental Safety, 69: 112-120.

Simonato, J. D., M. N. Fernandes \& C. B. R. Martinez. 2011. Gasoline effects on biotransformation and antioxidant defenses of the freshwater fish Prochilodus lineatus. Ecotoxicology, 20: 1400-1410.

Sloman, K. A., P. R. Desforges \& K. M. Gilmour. 2001. Evidence for a mineralocorticoid-like receptor linked to branchial chloride cell proliferation in freshwater rainbow trout. Journal of Experimental Biology, 204: 3953-3961.

Teles, M., M. Pacheco \& M. A. Santos. 2005. Sparus aurata L. liver EROD and GST activities, plasma cortisol, lactate, glucose and erythrocytic nuclear anomalies following short-term exposure either to 17 beta-estradiol (E2) or E2 combined with 4-nonylphenol. Science of the Total Environment, 336: 57-69.

Tiburtius, E. R. L, P. Peralta-Zamora \& E. S. Leal. 2004. Contaminação de águas por BTEX e processos utilizados na remediação de sítios contaminados. Química Nova, 27: 441-446.

Tintos, A., M. Gesto, J. M. Míguez \& J. L. Soengas. 2007. Naphthalene treatment alters liver intermediary metabolism and levels of steroid hormones in plasma of rainbow trout (Oncorhynchus mykiss). Ecotoxicology and Environmental Safety, 66: 139-147.

Vijayan, M. M., C. Pereira, R. B. Forsyth, C. J. Kennedy \& G. K. Iwama. 1997. Handling stress does not affect the expression of hepatic heat shock protein 70 and conjugation enzymes in rainbow trout treated with b-naphthoflavone. Life Sciences, 61: 117-127.

Wendelaar Bonga, S. E. 1997. The stress response in fish. Physiological Reviews, 77: 591-625.

Wendelaar Bonga, S. E. \& R. A. C. Lock. 2008. The osmoregulatory system. Pp. 401-416. In: Di Giulio, R. T. \& D. E. Hilton (Eds.). The Toxicology of Fishes. Boca Raton, CRC Press.

Submitted November 28, 2012 Accepted June 30, 2013 by Adalberto Val Published September 30, 2013 